Para enlazar con este artículo / To link to this article:

http://dx.doi.org/10.6035/MonTI.2019.ne4.11

Para citar este artículo / To cite this article:

Josephy-Hernández, Daniel E. (2019) "Reflections on the translation of gender in Perfect Blue, an anime film by Kon Satoshi." In: Pérez L. de Heredia, María \& Irene Higes Andino (eds.) 2019. Multilingüismo y representación de las identidades en textos audiovisuales / Multilingualism and representation of identities in audiovisual texts. MonTI Special Issue 4, pp. 309-342.

\title{
REFLECTIONS ON THE TRANSLATION OF GENDER IN PERFECT BLUE, AN ANIME FILM BY KON SATOSHI
}

\author{
Daniel E. Josephy-Hernández \\ daniel.josephy@gmail.com \\ Universidad Nacional de Costa Rica
}

\begin{abstract}
Perfect Blue (1997) is an anime (Japanese animation) film directed by Kon Satoshi. The film revolves around a female idol (a pop star) named Mima who quits her career as an idol to become an actress, and how she gradually loses her mind. This article presents anime as an important pop culture phenomenon with a massive influence worldwide. This article examines the gender stereotypes promulgated by this phenomenon and proposes a different reading of the work of Kon by comparing how the gender roles are portrayed in the different versions: The Japanese original and its yakuwarigo or "scripted speech" (Kinsui and Yamakido 2015) and the US English subtitles and dubbing. Methodologically, the analysis relies on close observation of the use of the Japanese first and second person pronouns and sentence-final particles in the characters' language, since "the use of these features is known to be highly gender-dependent" (Hiramoto 2013: 55). The study comes to important conclusions regarding gender portrayals in audiovisual translation.
\end{abstract}

\section{Resumen}

Perfect Blue (1997) es un film de anime (animación japonesa) dirigido por Kon Satoshi. Este film gira alrededor de una idol (una estrella pop) llamada Mima, quien decide terminar su carrera como idol para convertirse en una actriz y el subsiguiente declive mental que Mima sufre. Este artículo trata el anime como un fenómeno cultural pop con enorme influencia alrededor del mundo y analiza los estereotipos de género promulgados por ese fenómeno, además de proponer una lectura diferente de la obra de Kon. Se examina cómo los diferentes roles de género se exhiben en las diferentes versiones: en el original japonés y su yakuwarigo o «discurso guionado» (Kinsui y Yamakido 2015) y en las traducciones al inglés estadounidense. La metodología se basa en la observación 
del uso de los pronombres de primera y segunda persona y las partículas utilizadas al final de la oración del idioma japonés, ya que «the use of these features is known to be highly gender-dependent» («se sabe que el uso de estos rasgos lingüísticos están muy ligados al género del hablante») (Hiramoto 2013: 55). El estudio llega a conclusiones importantes respecto a los roles de género en la traducción audiovisual.

Keywords: Anime. Kon Satoshi. Perfect Blue. Audiovisual translation. Gender.

Palabras clave: Anime. Kon Satoshi. Perfect Blue. Traducción audiovisual. Género. 
Las películas son muy autoritarias, la mayoría dicen qué pensar; el cinema es casi un dictador (Miguel Gomes, Portuguese film director) $^{1}$

\section{Anime}

Anime, Japanese animation, is a powerful global media, with $60 \%$ of the animation worldwide being made in Japan (Goto-Jones 2009, 3). In Japan anime can be seen every day on many channels, with high-budget films appearing almost every weekend in theatres all over the country (today more and more anime films are being showed in theatres outside of Japan, mainly in the United States). In translation studies, most of the research on the translation of anime has concentrated on a narrow set of topics. Some authors have written studies on the translation of anime in a linguistic sense, e.g. O'Hagan (2003, 2009) and Condry (2013), others on fansubbing e.g. Díaz-Cintas and Muñoz-Sánchez (2006) and Pérez-González (2006), whilst others have placed their efforts into exploring the manipulation and censorship in anime, e.g. Parini (2012) and Josephy-Hernández (2015). The study of anime-its translation, dissemination and gender portrayals, amongst other topics-can undergo considerable expansion in translation studies. This article seeks to fill that gap, even if only so slightly.

\subsection{Kon Satoshi}

Born 12th October 1963, Kon Satoshi was a prolific manga artist and anime director. Kon was born in Hokkaidō, Japan. He directed four feature-length films: Perfect Blue (1997), Millennium Actress (2001), Tokyo Godfathers (2003), and Paprika (2006); as well as one TV series, Paranoia Agent (2005). This study deals with his first feature-length film, Perfect Blue.

1. "Films are very authoritarian, most tell you what to think. Cinema is like a dictator." Stated in a Q\&A at the Costa Rican International Film Festival, December 2015. 


\subsection{Perfect Blue}

Perfect Blue is based on the book by Takeuchi Yoshikazu named Päfekuto Burū: Kanzen Hentai. Working with screenwriter Murai Sadayuki, Kon changed the film's script so that it would suit his own taste and could be released as an animated film (Osmond 2006: 29). Perfect Blue is a psychological thriller, around 81 minutes long, about an idol (a female, Japanese pop star) named Kirigoe Mima (henceforth "Mima"), who decides, by herself, to quit her idol band Cham! and become a TV actress. As the movie progresses, we see Mima grow doubtful and fearful, unsure whether her decision to become an actress was the right one, whilst at the same time being stalked by a deranged fan. Mima rapidly descends into madness, causing her to confuse what is real and what is part of the show she is acting in.

Given the importance of gender portrayals in both image and language in anime, Kon's approach is striking: His portrayal of female characters is unique and serious, and does not follow the kawaii (cute) stereotypes seen in most anime, as it will be shown in this article. Mima is a woman who takes her own decisions, and does not live for anyone else-even if this affects her emotionally. Considering the importance of anime as a worldwide pop and social phenomenon, and the role played by audiovisual products as a "main vehicle of transmitting information, culture and ideology" (Chaume-Varela 2004: 7; author's translation), a critical look at how this often highly-sexualised material travels into other languages and cultures is an important step.

The reasons listed above motivated the author to analyse how Perfect Blue was translated, as it portrays gender in a manner atypical to most anime. This article concentrates on the use of First Person Pronouns (1PPs), Second Person Pronouns (2PPs), and Sentence Final Particles (SFPs) of the film's yakuwarigo (role language or scripted speech); it analyses how these were translated in the subtitled and dubbed versions of the films. This analysis is carried out in order to see if the gender roles expressed in the Japanese source text are maintained in translation. It is the author's hope that this study will be a critique of anime that will encourage further research in the area.

For these reasons, this study consists in describing and critically analysing the manner in which gender is portrayed in Perfect Blue in the "original" Japanese release, and how this portrayal is translated in the official subtitles and dubbings into US English. 


\section{Gender in anime and the Japanese language}

\subsection{Gender in anime}

Starting with a basic definition of gender, Judith Shapiro explains the difference between sex and gender, stating that sex relates to the biological differences between men and women, whilst gender refers to the social, cultural and psychological constructs that are imposed upon these biological differences (1981: 449). She argues that these constructs vary from one language to another, and one culture to another (Shapiro 1981: 449). The concept of gender means different things, for different people, at different times, in different socio-cultural, and even socio-political situations. The concept of gender can vary betweenand within—organisations, peoples, cultures and specific time periods.

In general, there has been one main tendency in the study of gender in anime, which is the study of shōjo (anime and manga aimed at a teenage female readership), and its variants, including mahō shōjo (the "magical girl") and yaoi (homosexual relationships between men). These genres have been the research focus of several scholars such as Allison (2006), Saitō (2001), Kotani (2006), Shamoon (2012), Pagliassotti, Nagaike \& McHarry (2013) and Saito (2014). Scott (2010) mistakenly labels Kon's Perfect Blue as shōjo (it is a psychological thriller). There is little work regarding Kon and gender, something that might be considered strange, since Kon expresses many opinions regarding gender roles in Japanese society. Yet this lack of academic work on Kon might be due to his underground status, something that remains the case even to this date.

\subsection{An overview of the genderlects of the Japanese language}

The Japanese language is "particularly a gender-marking language" (Furukawa 2016: 1) that denotes the sex of the speaker (Tanaka 2004: 2). Tanaka explains that Japanese boys and girls are taught from an early age how to speak in a gendered way-and are expected to talk according to their sex-and this is reinforced through their formative years. Native speakers of Japanese will use different pronouns, sentence final particles and lexicon (Tanaka 2004:2), as well as verbs.

\subsection{Gender-specific linguistic markers of the Japanese language}

The analysis carried out in this research is very much inspired by the study of Cowboy Bebop by Hiramoto (2013). As mentioned before, this work analyses the 1PPs, 2PPs and SFPs of the film because "the use of these features is known to be highly gender-dependent" (Hiramoto 2013: 55). These linguistic markers 
can be divided into specific features relating to how strongly or moderately feminine or masculine they are, or whether they are neutral features (Okamoto 1995). Thanks to these markers, for example, the listener can discern if a character is presenting him or herself as male or female, even if it is not explicitly stated in the text. The reason for this is that male and female characters use specific markers according to their own gender, so even if, for example, in a text the reader does not know if a character is male or female, the reader will be able to discern the character's gender based on the way they speak. Inoue (2003: 319) explains that these particles reflect the "the socially-accepted and culturally-constituted gendered demeanor" of the Japanese language. Ide and Yoshida (1999: 471) provide a detailed chart on the SFPs used by adult males and females in different social situations (formal, normal, deprecatory). It is important to understand, however, that these markers are part of the yakuwarigo, which is now briefly explained.

\subsection{Yakuwarigo}

Yakuwarigo, or "role language" or "scripted speech" in Japanese is an area of study first proposed by Kinsui in 2001. It is "a set of spoken language features (such as vocabulary, grammar and phonetic characteristics) that can be psychologically associated with a particular character type. (Character's attributes include age, gender, occupation, social status, appearance and personality.)" (Kinsui \& Yamakido 2015: 30). Yakuwarigo is something that can be analysed "in fiction, popular culture, e.g., manga, anime, and beyond (the internet)" (Teshigawara \& Kinsui 2011: 37). Naturally the study of role language can be applied to anime, as "yakuwarigo is rampant in popular anime shows, as most of the characters are depicted in purposefully exaggerated manners. Roles such as protagonist, villain, sidekick, etc. are made transparent to the audience both visually and linguistically in mainstream anime" (Hiramoto 2013: 52). It is important, then, to examine the way a character speaks and how this might represent specific ideals of Japanese linguistic hegemony. Kinsui's yakuwarigo is singularly pertinent for this study, as the film Perfect Blue has a scripted speech. The following section provides some examples of the stereotypical language employed in anime. This section is included in order to compare these examples with the ones from Perfect Blue.

\subsection{Examples of "clichéd" feminine language used in anime}

In anime, female characters frequently use the request form -nasai that women in Japan are expected to use, instead of the -te imperative form which is the 
one only used by men (Tanaka 2004: 28). However, in anime the use of -nasai and -te relates more to whether a female character has a strong temperament or not. If she does not have one, she will use the request form -nasai, e.g., the Jeanne D'Arc character in episode 4 of the anime series Drifters (2016), a seinen series (aimed at adolescent boys and men). But if the character has a strong temperament, or is very angry, she will use the -te imperative form, e.g. Jo in episode 9 of the Little Women (1987) anime adaptation.

Female characters in anime also use very specific SFPs. An example of a recent anime would be Sound! Euphomium (2015), a slice-of-life series where the music club consists mostly of girls and where in episode 5 one of the characters uses the atashi (a moderately-feminine 1PP) and nanoni (a moderately feminine SFP). Or in the show Fuuka (2017), about a man who accidentally takes a picture of a girl's panties and the relationship that develops afterwards, the first two lines of dialogues in episode 2 end with the moderately-feminine SFP -no, and sometimes the highly-feminine SFP -nanoni. Mahō shōjo anime features female characters that speak in highly-stereotypical ways. For example, Sakura, from the Cardcaptor Sakura (1998) series, in which a girl must collect and defeat powerful cards in order to save humanity, says "chigauno" "That's not right") at the beginning of episode 39. Moments later, she ends another sentence with the SFP -nano. -No and -nano are respectively highly and moderately feminine SFPs. In another case, Tsukino Usagi, the main character of Pretty Soldier Sailor Moon (1992), says "donna tsukauno?" ("How can I use this?")

This is but a small sample of the way female characters speak in anime, and writing a more exhaustive corpus goes beyond the scope of this paper. However, in writing this section the author wishes to encourage people to pay more attention at the relation between how female characters speak in anime, and how they are characterised and graphically presented on screen. Because as Nakamura and Ōnuchi (2006) explain, when characters in specific gender roles are shown to children from an early age, those children will come to accept these images as the standard social and gender norms, and think this attitude towards women's gender roles is the way things are supposed to be.

Anime has a strong effect on the lives of its viewers, especially when the show in question is a popular children's anime like Pretty Soldier Sailor Moon. This effect happens because, as Hall (1980) explains, television programmes (this of course includes anime) are encoded with a meaning that is then decoded by the audience; this meaning then incites specific social practices that benefit a dominant ideology. For Hall the circulation of products is the equivalent of distributing specific social practices that are consumed through a specific product. Applying Hall's theories of the encoding and decoding 
of meaning through television to the particular case of Japanese media, the noticeable aspect to be observed is that these meanings, originally encoded in an anime, are thus transferred (or translated) and encoded in the plethora of products (e.g. CDs, (fan)magazines, etc. as shown in Perfect Blue) that are part of Japan's media-mix.

Even if, overall, some changes in the character portrayals may happen over time, these changes are confined, and "the power of corporate ideology over character types remains very strong, and sets limits on the permissible" (Gitlin 1979: 261). This is the heteronormative message ultimately encoded in most anime. And yet, as the author will demonstrate in the pages that follow, Kon Satoshi is different and takes a critical stance towards this heteronormative convention with a different portrayal of female characters in anime.

\section{Gender in translation studies and audiovisual translation}

Gender in translation studies is an area that has been studied amply, starting with the works of Lori Chamberlain (1988), Sherry Simon (1996) and Luise von Flotow (1997, 2011, von Flotow \& Scott 2016), dealing with how different notions of power can affect a translation, how women are erased from literature in translation, and how female translators can rework and retranslate an original text in order to make it a feminist one. Gender in audiovisual translation, however, is an area with some sporadic research. Von Flotow $\&$ Josephy-Hernández (forthcoming, 2018) identify three main trends in the portrayal of gender of audiovisual products:

1) The first approach analyses AVT materials for the accuracy in which they reflect the feminist content and nuance of the original text, e.g. in Chiaro (2007), Bianchi (2008), Feral (2011), and DeMarco (2006, 2012).

2) The second approach addresses differences between subtitled and dubbed versions of a same product, e.g. in Feral (2011a), and in this article.

3) The third approach examines other sexual orientations and linguistic representations in/through translation, e.g. in the works of Lewis (2010), Asimakoulas (2012), and Ranzato (2012).

In the first approach, for instance, Bianchi (2008) explains that Buffy herself is dubbed in a manner that she is "tamed and normalized" (191ff) to the stereotypical ideas of Italian female sexuality. In the second approach, Feral (2011a) describes that whilst the French subtitling of Sex and the City shows 
powerful and successful women, the dubbing seems to place less emphasis on "female education, skills, ambition and success" (399). Finally, in the third approach "both Lewis and Ranzato find that the terminology available in Italian or Spanish for 'queer' ways of being and expressing oneself is either non-existent or weak, and often simply erased and replaced with more conventional language" (von Flotow and Josephy-Hernández, forthcoming 2018).

A translator can decide to follow a government's or company's regulations (labelled as what is "morally right" by their own standards), and in doing so, further foment, for instance, a heteronormative way of thinking that diminishes women's importance and intelligence. With audiovisual products-like anime - the impact is much higher because the medium in which the translation is disseminated is enormous and far-reaching, experienced by immeasurably broad audiences.

\section{Data analysis}

The data was obtained from the official DVD released by Manga Entertainment in 1999. The DVD contains the film in Japanese, as well as the English subtitles, the English dubbing, some extras, and a pamphlet. For the analysis the scenes were chosen based on the characters' gender, and whom they were addressing, i.e. their interactions. The scenes were selected if they were female-male (e.g. Tadokoro and Rumi), female-female (e.g. Rumi and Mima), and if Mima (the film's main character) was speaking to herself or with Phantom Mima. Controlling for these specific kinds of interactions helped produce a corpus that would provide answers to the research questions. For the data analysis, every single version of each scene was transcribed on a dialogue-per-line basis, starting with the original Japanese text, followed by the official English subtitles and the official English dubbing. Finally, each scene is analysed under the lens of the gender and translation aspects; first concentrating on how the lexicogrammatical features (the 1PPs, 2PPs, SFPs) were translated.

\subsection{Gender-specific language in Kon's Perfect Blue}

In this section I will discuss the gender-specific language that Kon's characters- specifically, the fans, Tadokoro (a man), Rumi (a woman), Me-Mania (a man), Mima and Phantom Mima-use in Perfect Blue. This is important to explore in order to see to what extent Kon's critique of gender practices/roles in the Japanese "idol" industry is reflected in the language assigned to these characters. 
- Mima: Mima is an interesting case, as she speaks in a neutral manner, seldom using feminine forms. This may be due to the fact that her behaviour is atypical for female characters in anime. Her individuality and resistance to the required norms is reflected in her speech. One example of this is that she uses the 1PP "Watashi" (I/me) during the entire film, e.g. "Kore ha watashi janai!", "Watashi ha hon mono dayo". Only very early does she use the more feminine forms "atashi/ atakushi": "Atashi ga Mima yo!" She does, however, use more feminine SFPs, such as "yo". This is but a small sample showing that Mima does not use a feminine language; more examples are provided in the analysis.

- "Phantom Mima": Mima's alter ego, an illusion, speaks in a more feminine manner than Mima does. This seems reasonable, given the situation, in which Phantom Mima is a reflection of a Mima who never stopped being an idol. For instance, Phantom Mima says "Atarimaeyo kore ga hontō no Mima damon" ("No wonder, this is the real Mima!"). In this case, damon is a highly-feminine SFP, discussed afterwards.

The 1PP, 2PP and SFP, as well as the keigo used in Perfect Blue provide the linguistic basis for the analyses of the gendered-linguistic interactions in this film They are the focus of this study's translation analysis and discussion, with special attention to variations of female/male differentiations in the film's language. The language choices made by the characters are relevant to understanding not only the relations between them, but also to gaining a perspective on Kon's view of their interactions.

- Mima's managers: When Mima's managers, Tadokoro and Rumi, discuss what to do about Mima's future, Tadokoro initially speaks in a soft manner with the use of feminine SFPs like dayou. But as the discussion progresses and Tadokoro becomes more frustrated with Rumi because of their argument, he uses the more masculine forms of the verb desu, such as darou and dazou. Rumi, in response, however, uses a standard form of the language with the SFP "desuka?"; this indicates that as a woman she positions herself in a lower social rank than Tadokoro, a man (as Tadokoro can use highly informal forms of verbs, while Rumi must use formal forms of the verbs). However, when Tadokoro needs to convince Rumi of his perspective or impose himself, he speaks in a more powerful manner by using the stronger, masculine form of verbs. What can be observed here, then, is that although Tadokoro and Rumi 
have the same social rank as Mima's managers, Rumi inhabits a lower position because she is a woman. This is shown in their speech.

In a different scene, when Rumi is explaining the internet to Mima, Rumi uses very feminine SFPs like dayo and nano (especially the latter). She speaks and acts in a strongly stereotypical feminine manner. Toward the end of the movie, when she is trying to kill Mima and says "Mima ha futari mō iranain damon", she uses a SFP damon that is highly informal and feminine. In other words, as Rumi progressively loses her mind, she becomes more feminine in her attitudes and the way she speaks, i.e. she tries to become more like the idol that Mima once was. This does not mean that "madness" is expressed through an overly feminised language, but that when a deranged Rumi reverted to an idol stage she employed the feminine language frequently used by idols.

- The fans: at the beginning of the film, the "wota" (idol fans) employ the informal verb "to be - dayo". In this first scene, the fan speaks in a stereotypical, informal manner, referring to Mima as Mima-rin. In another scene, however, where the fans are talking sarcastically about Mima's acting, they use the highly-masculine SFP -na, perhaps to use a strong language to disrespect her not only through the content of what they are saying, but also by means of how they say it. There are only a couple of instances in which the fans speak: Most of the scenes revolve around them as an audience, or concentrating on Mima's biggest fan, Me-Mania (who himself only speaks in one scene).

- Me-Mania: Me-Mania's few utterances are held in a highly-masculine manner. When he is assaulting Mima, he says "Boku no daijina Mimarin wo mamorunda!" using a masculine form of "I", boku, and an informal yet not explicitly masculine, SFP $n d a$. This is clearly a soto situation, as he uses strong language towards Mima, even a pejorative omae (informal "you"), acting in a condescending, and even violent manner towards Mima and degrading her not only through his actions, but also through his language. The reason for Me-Mania using this highly-masculine SPFs will be further explained in the analysis, but it is basically a way for him to exert power on Mima.

\subsection{The scenes}

\subsubsection{Scene 1: Tadokoro and Rumi discuss Mima's future}

In this scene, Tadokoro, Rumi, and Mima have a discussion about Mima's future. Mima has already said that she wants to end her career as an idol and 
become an actress, and Tadokoro agrees with her wishes. Rumi, however, disagrees and believes Mima should remain an idol, and she asks Mima about her "real" feelings.

Figure 1. Rumi and Tadokoro discussing Mima's future. ${ }^{2}$

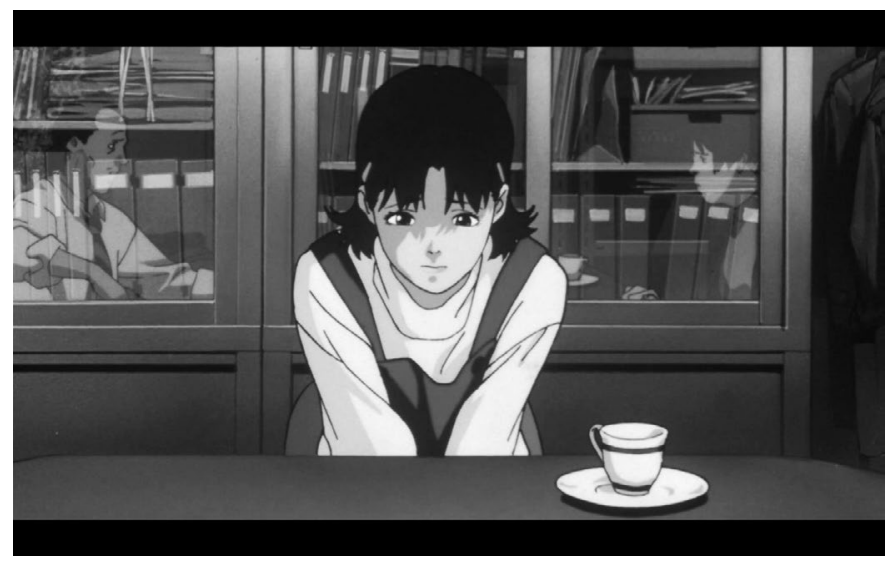

Example 1. 00.04.27-00.04.48

\begin{tabular}{|l|}
\hline \multicolumn{1}{|c|}{ Japanese Romaji } \\
\hline Tadokoro: Mima ha aidoru yori joyū ni muiterun dayo. \\
Rendora no regyuraa ni doukatte iun da. \\
Konna ii hanashi na ii darouga \\
Rumi: Uta to no kengyo datte ii jaanai desuka? \\
Tadokoro: Hokano futaritono sukejyuuru datte mou kamiatte nai darou! \\
Rumi: Joyū ni narutameni kibishii ressun wo ukete kitawake jya arimasen! \\
Tadokoro: Kyoku no purodyuusa ha joyū no Mima wo zessan shitekureten dazo! \\
Rumi: Datte, Mima no kimochi ga? \\
\hline \multicolumn{1}{c|}{ Back-translation } \\
\hline Tadokoro: Mima's talents are more suitable for acting than being an idol. She should \\
really accept this drama job. She might never get this offer in the future again. \\
Rumi: She can sing and do something else, no? \\
Tadokoro: The schedule of the other two is starting to mismatch. \\
Rumi: She did not take all those harsh lessons for no reason. \\
Tadokoro: The TV producer praised Mima's acting. \\
Rumi: But what happens with Mima's feelings?
\end{tabular}

2. All images are copyright of their respective owners. (C) MADHOUSE Inc, (C) Manga Entertainment, (C) Kon Satoshi. 


\begin{tabular}{l} 
Official Subtitles \\
\hline They want her in a drama series. \\
There are no better deals than this! \\
She can act AND sing! \\
That should be all right! \\
Her schedule with the other two \\
is already starting to mismatch! \\
She didn't go through those \\
hard lessons to become an actress! \\
The TV producer praised Mima's acting! \\
But what about MIMA'S feelings!? \\
\hline \\
\hline Tadokoro: Mima should be acting, not singing! \\
They want her in a drama series, you just don't pass up on a deal like this! \\
Rumi: She can do both, she can sing and act! \\
Tadokoro: Her schedule with the other two has already created a difficult problem! \\
Rumi: Listen, she didn't go to all those singing lessons just so she could become an \\
actress! \\
Tadokoro: The producer of the show doesn't care! He thinks Mima's a wonderful \\
actress! \\
Rumi: Of course! But what about Mima's feelings?
\end{tabular}

In the original Japanese version, Tadokoro initially uses a soft SFP $-y \bar{o}$ in his line. But as the conversation progresses, he becomes increasingly exasperated with Rumi, and his demeanour intensifies. The result is that he begins to use a more masculine SFP, -zo. He does this to appear masculine and forceful as he takes a stronger stance-in his demeanour and language-against Rumi.

In contrast, Rumi uses neither formal nor informal language. Instead, she speaks in a neutral tone with SFPs in verbs, such as desuka and arimasen. This distinguishes her dialogue greatly from Tadokoro's overall tone in the conversation, which is informal. Rumi's neutral manner betrays no femininity in her dialogue. The fact that Rumi speaks with this tone is a sign that she is taking a stronger position for herself in the conversation by using neutral, de-feminized language. By doing so, she ceases to have a lower status than Tadokoro in the conversation.

This situation can be seen in the film's images. Tadokoro has a relaxed demeanour throughout the conversation, waving his hands as if to dismiss Rumi's statements. Rumi, however, looks directly at Tadokoro and places both of her hands on the table, fists closed, in order to project a powerful, angry attitude. Tadokoro is a man, so his style of conversation is that of a business 
discussion in a smoke-filled room or a bar (although in uchi context, he personally knows both Rumi and Mima). As a woman, Rumi must speak in a neutral manner and behave forcefully to get her point across to Tadokoro.

In the subtitles, Tadokoro is translated as speaking in a standard manner with short sentences, although he has more lines than Rumi. Every one of his sentences, with the exception of his first, ends with an exclamation sign. This allows the viewer to understand, along with the images, that at the moment he is speaking he is taking an assertive stance.

In Rumi's utterances the word "and" is in all capitalised letters in her dialogue - an uncommon occurrence in official subtitles-and there are exclamation points at the end of each sentence, along with a question mark and an admiration sign at the end of Rumi's last line. All these devices convey a degree of assertiveness, but not to the same degree as in the original Japanese script. It is notable, though, how the subtitler used limited space to represent Rumi's strong character in this scene.

The dubbing better preserves Rumi's steadfast manner compared to the subtitles. Not only does the dubbing provide a more forceful portrayal of Rumi's behaviour, but the fact that dubbing is an oral medium allows for specific control of the character's voice. In this instance, the dubbing presents a strong tone that better conveys Rumi's emphatic message. Rumi says "listen" before explaining to Tadokoro why she thinks Mima should stay an idol, even if she becomes an actress. Her delivery of this line emphasises her resolve: she says "listen," pauses and then rapidly lays out her argument. The first word serves to put Tadokoro on notice. Compared to the subtitles, the dubbed Rumi is a stronger one, even though Tadokoro has more space-again, his lines are longer-to convey his message.

\subsubsection{Scene 2: Cham! Departure}

In the following scene Cham! is performing their final concert together as a trio. During a pause in the set, Mima addresses the audience and informs them that she is leaving the group—or "graduating" from it—as Yukiko says it. But during this farewell address, a group of "punks" start to throw cans at the stage, and begin fighting with other people. Mima, frustrated by their behaviour marring her last show, forcefully pleads for the "punks" to stop. 
Figure 2. Mima says her farewell

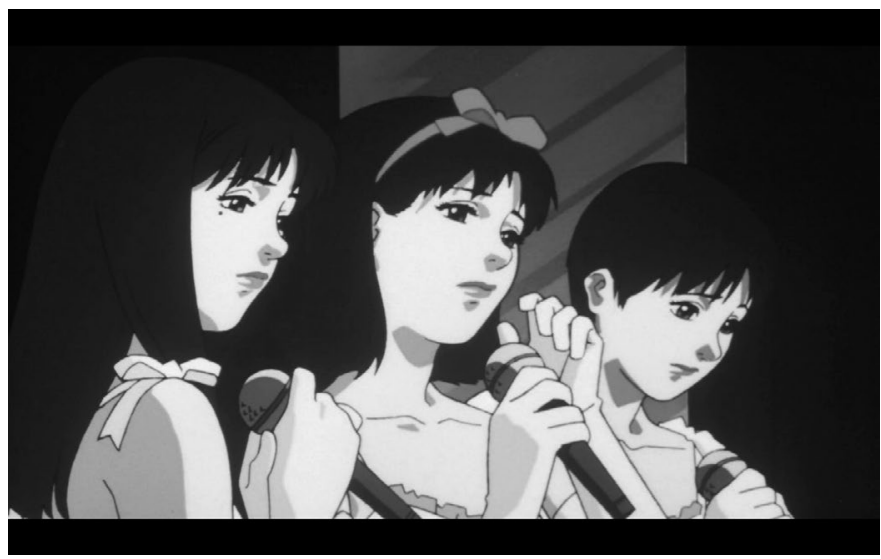

Example 2. 00.05.35-00.06.45

\section{Japanese Romaji}

Yukiko: Eeto... saigono kyoku no mae ni houkokushinakya ikenai koto ga arimasu Mima: Eeto... Watashi Kirigoe Mima ha Cham! no ichinen toshite...

Yamete! Kyō dake ha minna to tanoshiku sugoshi takattanoni

\section{Back-translation}

Yukiko: Hum... before our last song, we have to inform you of something. Mima: Hum... I, Kirigoe Mima, in this year in Cham...

Stop! Just for today I wanted to have a good time!

\section{Official Subtitles}

Umm... Before our last song,

we have news to tell you...

Um, I, Mima Kirigoe,

had a fun time as a member of CHAM...

Stop it!

Today...

Just today...

I wanted to have a good time with all of you!

Official Dubbing

Yukiko: Hum, but before we sing our last song, we do have some news we would like to share with all of you!

Mima: Ah, I, Mima Kirigoe, had a really fun time being a member of Cham! [...]

Mima: Stop it now!

Tonight... I mean today, I just wanted us to, please, just have a good time! 
In the Japanese version of the script, what is immediately noticeable is the number of pauses on part of all the members, especially Mima. She is clearly sad about having to tell her fans that she is leaving Cham! In this text, Yukiko starts off by saying "ee..." and "eeto..." Even Mima says eeto once herself. Eeto is a common phrase used by women in Japan, usually to express doubt. In this scene, it is used as vocal filler to convey the hesitation of the characters speaking on stage. The subtitled version of the dialogue, as expected, contains some differences from the Japanese script. Mima and Yukiko's pauses at the beginning of the scene are more noticeable. This is because they are graphically rendered with an ellipsis, demonstrating Mima's sadness, and perhaps doubt, over leaving Cham! There are also six pauses in the subtitles, as compared to five in the dubbing.

In the Japanese text, Yukiko uses the standard form of the verbs, as does Mima. When Mima wants to stop the fighting, however, she uses the word "yamete" ("stop"). The -te imperative form is a strong imperative more commonly used by men than women (Hiramoto 2013: 60), or according to Tanaka (2004: 28 ), only by men. Tanaka explains that "women are expected to use the -nasai suffix, which is added to the verb base" (Tanaka 2004: 28). In other words, Mima would be expected to use yamenasai instead of yamete in this situation.

Mima's use of yamete is a stark contrast to the hesitant Mima that was using eeto, while pushing back her hair and looking down at the floor. The impact of Mima's use of the -te imperative is enhanced by the film's visuals, which feature a close up of her mouth as she speaks into the microphone. This, coupled with Mima's use of the standard 1PP watashi instead of the more feminine atashi or atakushi, provides evidence to the viewer that Mima is not a typical female anime character.

Interestingly, the heightened hesitation in the subtitles does not diminish the ferocity of Mima's response when the ruckus in the audience takes place. Mima uses the imperative yamete when she addresses the hooligans. She again does not use the more common imperative form for women in Japan, -nasai, or yamenasai in this case. She adamantly insists that the troublemakers stop the commotion, using a strong verb form. This might be because she is in a soto situation with the fans, she can use a use a stronger verb form than she would use in an uchi situation. This is expressed in the same emphatic manner as in the subtitles when she yells "Stop it!" rather than a more subdued "Please stop." The dubbing portrays her resolve in an even stronger way, as it has her yelling "Stop it now!" This strong language, along with Mima's high-pitched voice, gives the dubbing the forceful Mima we also see in the original Japanese script, meaning that, concerning "the gender question", Mima is as strong a female character in the dubbing as she is in the Japanese script. 


\subsubsection{Scene 3: Mima and Rumi talk about the fan blog about Mima}

In this scene, Mima and Rumi have a brief discussion about a letter Mima received earlier from a fan detailing a blog called Mima's Room. It occurs right before Mima is about to speak her first lines in Double Bind. Mima asks Rumi to explain a blog to her, and Rumi tries to explain what it is. Mima still does not understand, even after Rumi's explanation.

Figure 3. Mima and Rumi

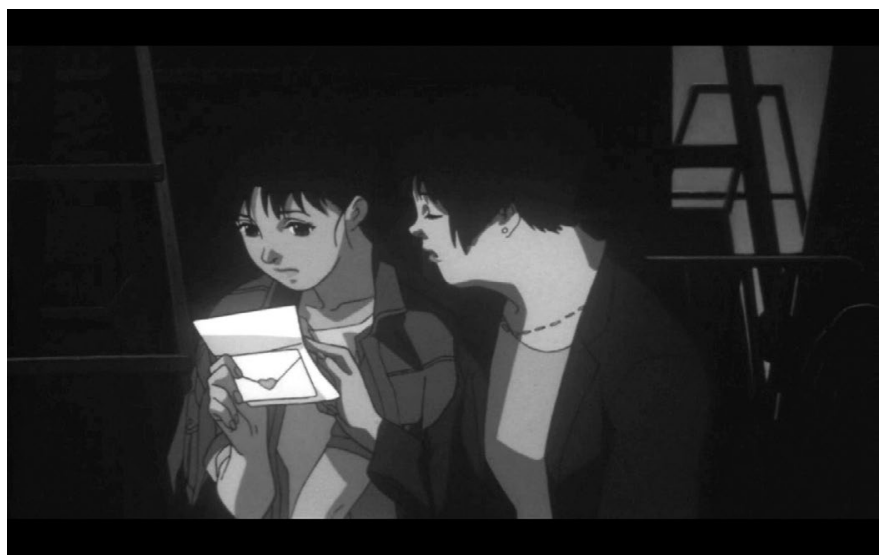

Example 3. 00.13.38-00.14.12

\begin{tabular}{l}
\multicolumn{1}{|c|}{ Japanese Romaji } \\
\hline Mima: Ne ne Rumi-chan, wakatta? Sore? \\
Rumi: Kore intaanetto no hoomu peeji dayo. \\
Mima: Aa saikin hayatteru are. De nan nano sore? \\
Rumi: Nn- nanteittara ii no kana? Pasokon tsuushin mitai namon nanda kedo ne. \\
Mima: Sorede... \\
Rumi: Kono Mima no heya ni rinku hattate koto ha kono Kono Mima no heya tenomo \\
hoomu peeji no namae nano. Sappari? \\
Mima: Un! Sappari! \\
\hline \multicolumn{1}{|c|}{ Back-translation } \\
\hline Mima: Rumi do you understand this? \\
Rumi: This is a homepage on the internet. \\
Mima: Ah, that new popular thing. So, what is it? \\
Rumi: What can I say? It's like computer networks. \\
Mima: And... \\
Rumi: With this link attachment you can access Mima's room, and Mima's Room is the \\
name of the website. Got it? \\
Mima: Nope, I don't get it.
\end{tabular}




\begin{tabular}{|c|}
\hline Official Subtitles \\
\hline $\begin{array}{l}\text { Do you know what } \\
\text { that note means, Rumi? }\end{array}$ \\
\hline It's an Internet home page. \\
\hline Oh, that thing that's been popular lately! \\
\hline$\ldots$ and what is it? \\
\hline How can I describe it? \\
\hline It's kind of like computer networks. \\
\hline And? \\
\hline Considering that this person "put up a link to Mima's Room"... \\
\hline ... this "Mima's room" thing is the title of a web site. \\
\hline You don't get it, do you? \\
\hline Nope, not one bit. \\
\hline Official Dubbing \\
\hline $\begin{array}{l}\text { Mima: What do you think, Rumi? Do you know what it means? } \\
\text { Rumi: It's just a website, somebody took it off the internet. } \\
\text { Mima: Oh, that's really popular lately! Huh, so what's it mean? } \\
\text { Rumi: Hmm how can I describe it? It's kind of a like networking by using the } \\
\text { computer. } \\
\text { Mima: Yeah and? } \\
\text { Rumi: Well it looks like this person, whoever it is, put up a link to Mima's room, which } \\
\text { is the title of the website. That makes sense? } \\
\text { Mima: Hum, not one bit! }\end{array}$ \\
\hline
\end{tabular}

In the original Japanese script, Mima uses the informal past form of wakaru ("to understand") when she asks Rumi "wakatta?" ("did you understand?"), as well as the informal "uun" (which Mima also used when speaking with her mother on the telephone). This tone indicates that it is a familiar interaction, as Mima and Rumi know each other. Rumi speaks in an informal manner with Mima, using feminine SFPs such as -yo ("right?"). Both Rumi and Mima Rumi also use the moderately-feminine SFP -nano. In the Japanese script Rumi addresses Mima in a motherly tone, as if explaining to a child how something works, using longer sounds, especially longer vowels.

Rumi's motherly relationship with Mima is lost in the subtitles, however. She simply states-and because of lack of space, quite rapidly-the concept of a blog. The dubbing does not address this either, as Rumi speaks quickly to Mima, rather than slowly explain a blog to her as a mother would to a child. This demonstrates that the people who worked on the subtitling and dubbing 
did not notice Rumi's tone in the original Japanese script, something that probably requires several viewings of the film to detect. The dubbing misses a subtle cue about the state of Rumi's declining sanity. It shows her fatigue-she is yawning from lack of sleep at the beginning of the scene-but it also portrays how much Rumi cares about Mima, and how she is trying to support Mima's decisions with the faculties she has left.

At the end of her explanation about the blog, Rumi asks Mima if she understands-Mima states she does not. In the Japanese script, Rumi asks her "Sappari?" which is an adverb that means "at all" (in other words, she asks "Do you understand at all?"). Mima replies with an informal "un!" ("Yes"), followed by "Sappari!" ("Not at all!"). In the dubbing, Mima and Rumi converse in an informal manner, with Rumi asking her "That make sense?" to which Mima replies "Hum, not one bit!" The dubbing portrays an informal interaction, with Rumi omitting the verb "does" from the sentence. It is, however, different from the subtitles, where instead Rumi asks Mima the question "You don't get it, do you?" Mima replies "Nope, not one bit". The two characters in the subtitled version of the scene use, then, what Lakoff (2004) and Hiramoto (2013) label an expected way for women to speak with the use of tag-questions. The use of these questions portrays Rumi speaking to Mima in a condescending way, implying that Mima is ignorant and lacks knowledge of the Internet. Mima's reply in the subtitled version is similar to hers in the dubbing, but the way Rumi's question is phrased ends up emphasising Mima's lack of knowledge about the internet.

\subsubsection{Scene 4: Phantom Mima and Mima interact}

In this scene, Mima begins to definitively lose her mind. The Phantom Mima that has sporadically appeared throughout the film now addresses her directly. She tells Mima that her reputation is "tarnished" due the rape scene she performed, and that no one likes an idol with "that kind of reputation". Mima, stupefied, asks Phantom Mima to reveal her identity. The illusion cryptically replies that she will be taking the spotlight instead of Mima. 


\section{Figure 4. Phantom Mima and Mima}

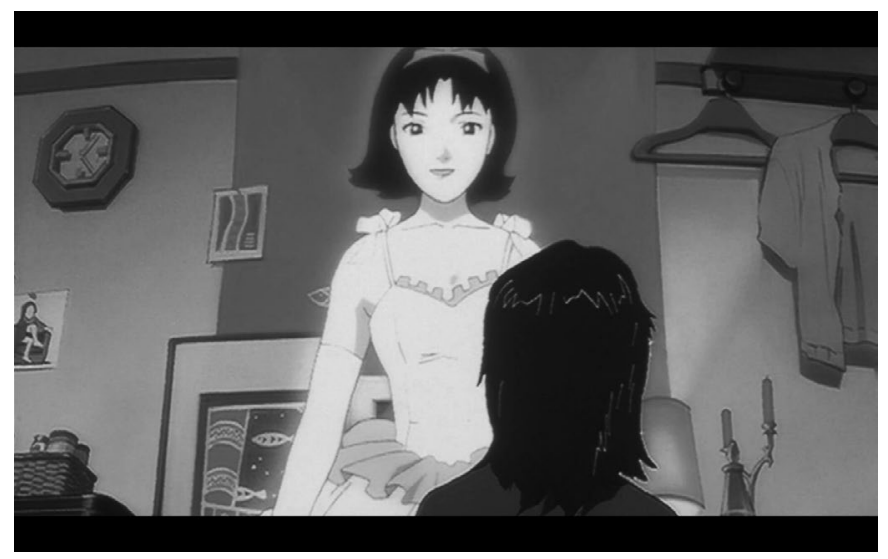

Example 4. 00.39.18-00.40.30

\begin{tabular}{l} 
Japanese Romaji \\
\hline Mima: Chigauyo! Kore ha watashi janai! \\
Phantom Mima: Atarimaeyo kore ga hontō no Mima damon. Hontō ha aidoru ni \\
modoritai to omotterukuseni! \\
Mima: Chigau datte watashi ha mō... \\
Phantom Mima: Watashi ha mō? Souyone mō aidoru nankajya naimon ne. Datte anata \\
ha mō yogorechatta mono. Yogoreta aidoru nante daremo suki ni nanai yone? \\
Mima: Chigau! Chigaumon! \\
Phantom Mima: Anata ha mō ano hikari no naka niha modorenai. Demo iino watashi \\
ga irukara. Kore kara ha watashi ga hikari de anata ga kage yo. \\
Mima: Nani itteruno? Anata dare nano? \\
Phantom Mima: Dare mo anata nante suki janai. Yogorechatta! \\
Mima: Yamete yametettara! Watashi ha yogoreranakyia! Matte! Matte! \\
\hline \multicolumn{1}{c|}{ Back-translation } \\
\hline Mima: No, this is not me! \\
Phantom Mima: No wonder this is the real Mima. The real one wants to return to being \\
an idol again. \\
Mima: No, I am no longer... \\
Phantom Mima: No longer what? You're saying you don't want to be an idol, but you're \\
tainted. So you're already tainted. And nobody likes tarnished idols, right? \\
Mima: No no! \\
Phantom Mima: You can no longer be in the spotlight. But it's all good, I am here. From \\
now on, I will be in the spotlight instead of you! \\
Mima: What are you doing? Who are you? \\
Phantom Mima: Nobody likes you anymore. Tainted tainted! \\
Mima: Stop, stop! I am not tainted... wait, wait!
\end{tabular}




\section{Official Subtitles}

This... This isn't true!

I'm not writing any of this!

Of course! The REAL Mima is writing this!

I know that deep down in your heart

you want to be a pop idol again.

No!

I'm no longer...

No longer what?

Oh yeah, you're no longer a pop idol.

You're a filthy woman now.

Nobody likes idols with tarnished reputations!

That's not true! That's not true!

Mimarin!

You can't step back into that spotlight now...

But that's all right. I'M here.

From now on, I'll be in the light, and you'll be in the shadows.

What are you saying!?

Who in the world are you!?

Nobody likes you anymore.

You're tarnished! FILTHY!

Stop! Stop it!

I am not tarnished!

Wait!

WAIT!

\section{Official Dubbing}

Mima: What?? This isn't true, I didn't write this!

Phantom Mima: Of course you didn't! The real Mima is writing this! I know that deep down in your heart you want to be a pop-idol again!

Mima: No! It's not true! I'm no longer...

Phantom Mima: ... no longer, what...? Oh yeah that's right, you're no longer a pop idol! You're a filthy woman now, like a slut! No one likes a pop idol, with a tarnished reputation.

Mima: It's not true! It's not!

Phantom Mima: You won't be able to step back into that spotlight now! It's all right, you don't have to worry; I'm here. From now on, I'll be in the light, and you'll be in the shadows!

Mima: What're you saying?? Who in the hell are you?

Phantom Mima: Nobody cares for you anymore! You're tarnished, and, you're filthy!

Mima: Stop it! Stop it I am not tarnished! Wait... no! Wait...! 
In the Japanese script, both Mima and Phantom Mima address each other using a neutral language, employing 1PPs and 2PPs, such as watashi ("I") and anata ("you"). This is significant because it shows that even though Phantom Mima is a part of Mima, the two are separate entities in Mima's mind. This is demonstrated by the distance created by the use of the standard pronouns watashi and anata, instead of more familiar ones, such as atashi ("I") or kimi ("you"). Phantom Mima is a detached being that bluntly states her intention to take over the host. Mima also uses moderately-feminine SFPs such as -nano and -no. However, due to the intensity of the scene and Mima's confusion at Phantom Mima, I believe that the use of this SFP is actually Mima trying to place herself in a stronger, defensive position against Phantom Mima, to "assert herself", as Abe (1998: 63) explains that women sometimes use female SFPs in order to take a stronger stance.

The language in this scene is much stronger in the dubbing than in the subtitles. In both, Phantom Mima tells Mima "You're a filthy woman now!" The dubbing, however, adds the phrase "Like a slut! - besides including Phantom Mima's insults of calling Mima "filthy" and "tarnished"-something that increases the objectification of Mima. The subtitles, as a close rendering of the Japanese text, do not have this kind of addition; instead, the subtitles try to compensate the forcefulness by writing certain words all in capital letters, e.g. "REAL!" and "FILTHY!" These words are used to emphasise Mima's "dirtiness". No other words are added, and no modulations are carried out in order to convey this feeling. Hence, the subtitles emphasise Mima's dirtiness through capitalisation, but the dubbing has a "dirtier" portrayal of Mima compared to the original Japanese version by making Phantom Mima insult Mima more through the use of expletives that were not part of the Japanese script.

\subsubsection{Scene 5: Me-Mania attacks Mima}

In this scene, Me-Mania attacks Mima in the same movie set where she was gang-raped for the Double Bind series. This is, in fact, the only instance in Perfect Blue where Me-Mania and the real Mima interact face to face and engage in dialogue. Me-Mania hits Mima, momentarily knocking her out, and gets on top of her. But as Me-Mania salivates over Mima's naked body, Mima reaches for a hammer on the set and hits him in the head. Me-Mania dies screaming just moments later. 
Figure 5. Me-Mania attempting to rape Mima

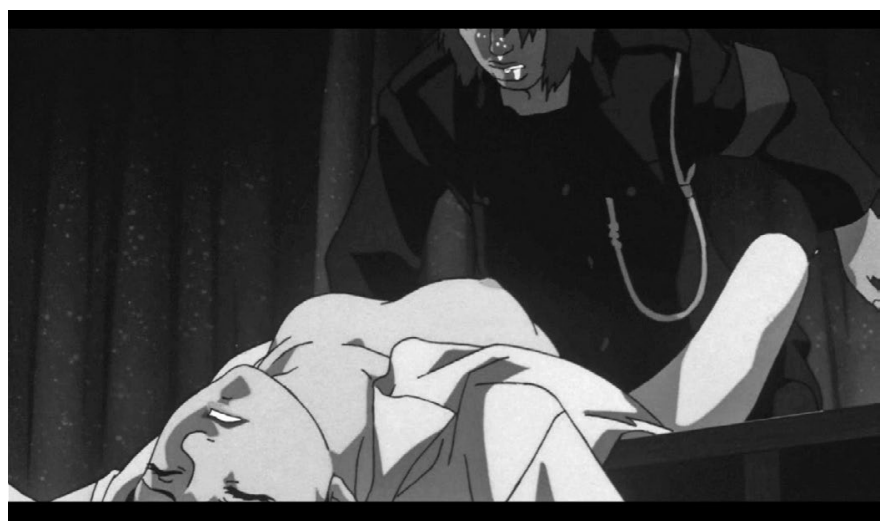

Example 5. 01.04.11-01.05.07

\section{Japanese Romaji}

Mima: Dareka tasukete!

Me-Mania: Omae no koe nanka dare ni mo todokumonka!

Mima: Anata dare? Doushite konna...

Me-Mania: Boku no daijina Mima-rin wo mamorunda!

Mima: Watashi... watashi ga Mima yo!

Me-Mania: Chigau chigau chigau chigau chigau! Boku ga Mimania datte siranakatta jyanaika. Mimarin no huri shiyagatte!

Mima: Aa yamete! Iie! Iie!

Me-Mania: Kono kuchi de ano raitaa yara kameraman wo tarashikon danoka? Mimarin wo yogoshi yagatte!

Mima: Masaka anata ga...

Me-Mania: Hontō no Mimarin ha mainiti bokuni meeru wo kurerunda. Omae ga jyama bakkari surutte

Mima: Anata ga koroshitano?

Me-Mania: Mousugu omae mo na!

Back-translation

Mima: Somebody help me!

Me-Mania: Nobody is able to hear your voice!

Mima: Who are you? Why are...?

Me-Mania: I am protecting my dear Mima!

Mima: I, I am Mima!

Me-Mania: No no no no no! You don't know this. There cannot be an impostor Mima. Mima: Ah stop, no no!

Me-Mania: Did you trick the writer and cameraman with that mouth? You dirtied

Mima!

Mima: Don't tell me you...

Me-Mania: The real Mima emails me everyday! You're getting on the way!

Mima: Did you kill them?

Me-Mania: And soon so will you... 


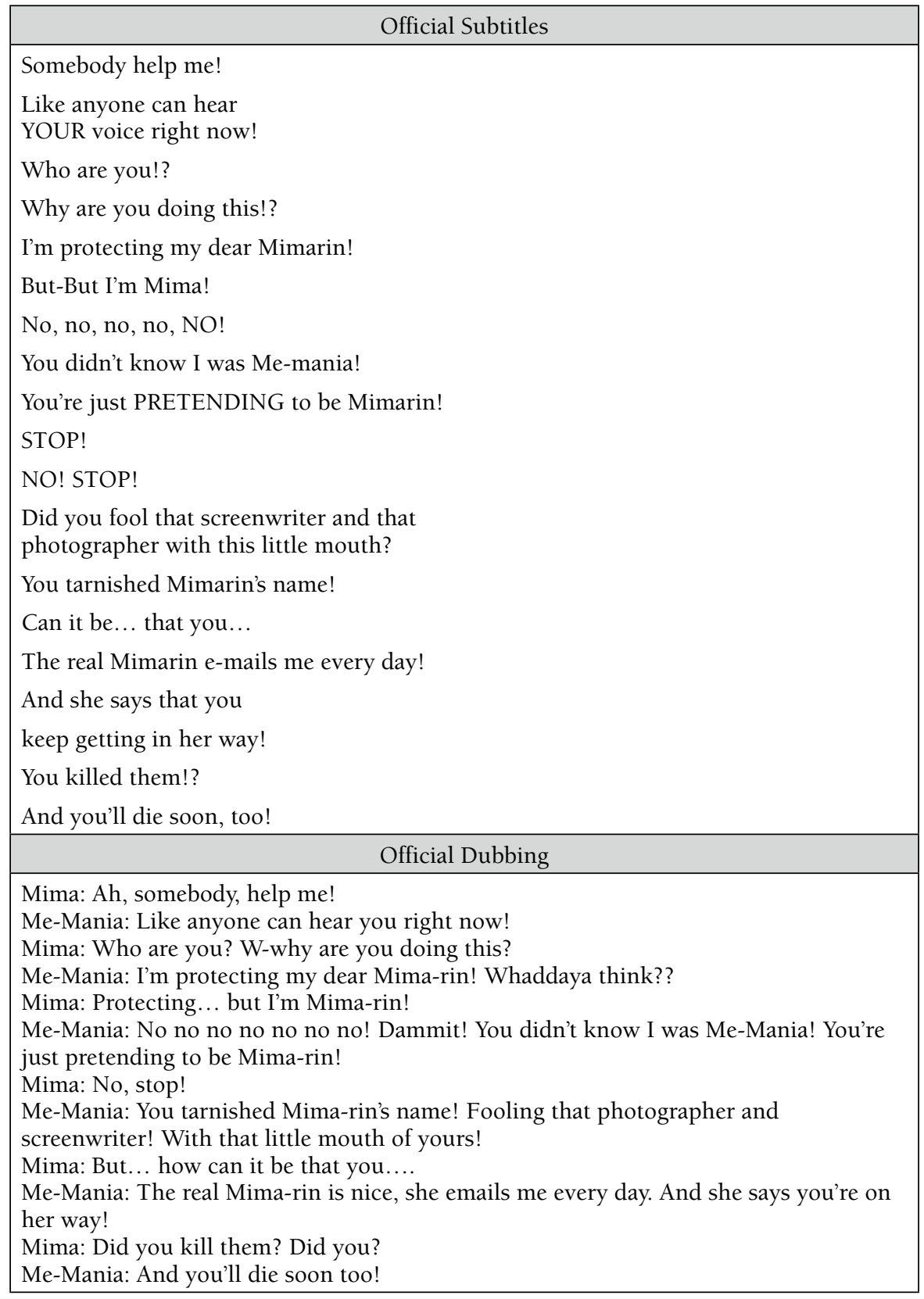

In the Japanese script, Me-Mania uses the 2PP omae to address Mima. Omae is a very informal pronoun, and Me-Mania uses it pejoratively towards Mima. 
By employing this specific pronoun, Me-Mania shortens the psychological and social distance between himself and his victim. This serves to bring Mima down from her status as an idol and actress, into one that is below Me-Mania. This allows him to exert physical and psychological control over her through his attempt to rape her, and the use of the overly pejorative omae.

Although Me-Mania uses a pejorative pronoun, omae, towards Mima, and a slightly-masculine one, boku, for himself, Mima keeps Me-Mania off by using the neutral anata ("you") and watashi ("I"). She is in extreme distress and is keeping a linguistic distance from him. Mima uses the -te imperative form, which is used mostly by men (Hiramoto 2013, 60), when she says yamete ("stop"), something expected under these dire circumstances. Mima also uses the moderately feminine SFP -no in "koroshitano?" ("killed"), but as Abe (1998) explains, by using this particular SPF she is not being weak, rather, she is asserting herself. This also contrasts with the highly-masculine SFP Me-Mania uses in -mona. Me-Mania and Mima are not only clashing physically, but also verbally: Me-Mania is attempting to rape Mima and refers to her pejoratively with omae whilst also using highly-masculine SFPs like -mona, whilst Mima is pushing Me-Mania away and using imperatives (instead of requests), as well as feminine SFPs such as -no in order to get away and survive.

Me-Mania in general speaks in a pejorative tone towards Mima in this scene. His tone is one of complete disdain towards the idol he says he loves. He also curses at Mima in the dubbing, attacking Mima in a different manner than the Japanese version. In the dubbing Mima pauses several times during the confrontation (e.g. "W-why", "But... how can it be you...") which are not part of the Japanese version. This is a hesitation that is added to Mima's character, although it does not make her look weak, just simply frightened.

The dubbing also has an interesting translation of one of Me-Mania's lines. He tells Mima "Kono kuchi de ano raitaa yara kameraman wo tarashikondanoka? Mimarin wo yogoshi yagatte!," which the dubbing translates as: "You tarnished Mima-rin's name! Fooling that photographer and screenwriter! With that little mouth of yours!" In the subtitles, he says: "Did you fool that screenwriter and photographer with this little mouth? You tarnished Mima-rin's name!" The dubbing has a slight, but significant difference. By adding the possessive "that little mouth of yours", the tone of the line becomes more pejorative than the "This little mouth" used in the subtitles.

\subsubsection{Scene 6: Final scene: "I am who I am!"}

In the film's final scene, we see Mima visiting Rumi at the mental hospital, with the sky coloured "blue". Rumi never recovers from her mental breakdown and 
still believes she is Mima the idol. On her way out of the hospital, Mima overhears two of the nurses debating whether she is "the" famous Kirigoe Mima. This lets the viewer know that Mima has become a successful actress, but the nurses conclude it cannot possibly be her because they (wrongly) assume Mima would have no reason to visit the hospital. Mima walks on by and gets into her car. The final shot features Mima looking at herself in the mirror, and speaking the film's final line, says:

Figure 6. Mima staring at the rearview mirror in the film's final scene

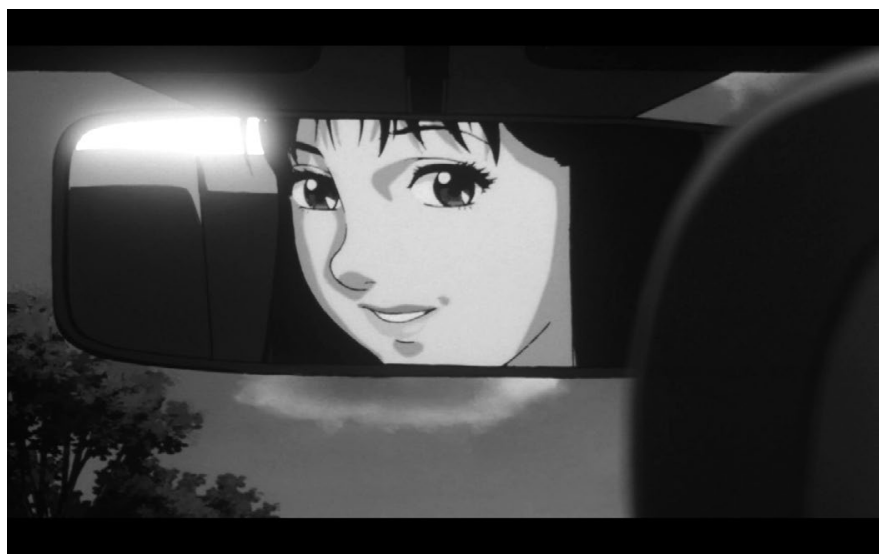

Example 6. 01.17.39-01.17.42

\begin{tabular}{|l|}
\hline \multicolumn{2}{|c|}{ Japanese Romaji } \\
\hline Mima: Watashi ha hon mono dayo! \\
\hline \multicolumn{2}{|c|}{ Back-translation } \\
\hline Mima: I am the real thing \\
\hline \multicolumn{2}{|c|}{ Official Subtitles } \\
\hline No, I'm real! \\
\hline
\end{tabular}

In the Japanese script, Mima says "watashi ha hon mono dayo", which literally means "I'm the real thing". Mima, as in most other places in the script, uses the standard 1PP watashi, instead of the more feminine forms atashi or watakushi. She also uses the SFP -yo, which is normally used by both male and female speakers of the language. In other words, the language Mima employs in this 
phrase is not particularly feminine-as in most of the other cases where she speaks_but neutral.

In the subtitles, this line is translated as "No, I'm real!" This line shows that Mima is finally able to distinguish between reality and fantasy, although the ending is open to interpretation. Both the dubbing and the subtitles show an assertive Mima, herself convinced that she is real. Even if the translations are simply conveying the intended message of the Japanese script, and do not take into account Mima as a character and her particular use of watashi (instead of atashi, for example), this last line of the script reflects the ongoing characteristic of the film's subtitles and dubbing: That the unmanipulated manner in which the film was translated means that the message of the Japanese text is undiluted.

\section{Analysis and Conclusions}

The analysis of Perfect Blue and the differences between its many versions has led the author to the following conclusions. The first finding is that the official subtitles of Perfect Blue provide a close rendering of the original Japanese script. From the standpoint of the translation of gender, the subtitles do not translate some of the nuances that make Mima a strong female character in the Japanese script, e.g. use of imperative forms, standard—not feminine-1PPs, neutral SFPs, as well as the feminine SFPs when she wants to assert herself. Kon chose to make Mima speak in a particular way, to have a specific yakuwarigo, as he wanted to demonstrate Mima's evolution as a person, from idol to actress. This evolution in Mima's personality, and her way of speaking, is not shown in either the subtitles or dubbing.

This happens with other characters as well. Rumi speaks in a standard manner when she is cogent (e.g. using neutral forms of verbs) and in a girlish, feminine manner when she becomes deranged (e.g. with the use of more feminine SFPs). Tadokoro speaks in a stereotypically masculine manner (e.g. with SFPs like -zo). Me-Mania is moderately masculine in his speech (e.g. using 1PPs such as "boku") despite his androgyny-visually speaking-as a character, and refers pejoratively to Mima by using omae. These strong feminine and masculine qualities of the characters are not expressed by the subtitles. The subtitles write specific, important words in capital letters (e.g. "SLUT!" for Phantom Mima), which help emphasise the attitudes characters may have towards one another, whether this concerns Mima's response to her rowdy fans, or Me-Mania's abuse towards Mima during his attempted rape. The subtitles, however, do not portray a weaker Mima, meaning that the feminist message 
Kon wanted to transmit is maintained in the subtitles, even if it is not as strong as in the Japanese script.

Last, but not least, the author found that the characters in the dubbing employ a stronger language, and harsher words, towards each other. This can be observed in the scene where Phantom Mima treats Mima in an extremely harsh manner compared to the Japanese script, calling her "a slut", a phrase she does not use in the Japanese version. The dubbing is more mindful of the nature of each scene, taking care to convey a message not only through what is said, but also by how it is said. Mima, for instance, is portrayed as a strong character throughout the film, with the tone of her voice accurately reflecting the intended linguistic meaning of her words (e.g. if Mima is angry, she sounds angry in the dubbing as well). Rumi is more inconsistent in this regard, as her tone varies from scene to scene. In the Japanese script, for example, she often behaves with a motherly touch in her interactions with Mima, yet she frequently sounds condescending in the dubbing. Rumi also uses more tag questions in the dubbing, as she follows the rules of how women are expected to speak both in Japanese and English (Hiramoto 2013).

The author, then, discovered that the script by Kon and Murai makes subtle shifts in the way the film's characters use these linguistic markers, and these are not taken into account in the translation. For example, when Mima goes from using moderately-feminine 1PPs and SFPs to neutral or ones, these shifts are not reflected in the subtitles and dubbing. The author hypothesized that there would be more to these linguistic markers in the English translation, but the fine distinctions Kon uses are absent in English.

Hence, it is my position that when translating anime (or any other form of Japanese material) from Japanese into other languages, it is crucial to take into account the characters' use of the 1PPs, 2PPs and SFPs. It is also critical that the translation remains consistent with the specific social context (the role and distance between characters) of a particular scene. Japanese is a gendered language, to the extent that the specific use of a 1PP, 2PPs or SFP can determine a character's status compared to the other. By minding the significance of these nuances when translating, the translator can convey a more accurate (or "inaccurate", depending on what the translator is aiming for) translation in the same constrained space. The study of how that is achieved is not the focus of this research, but it is certainly a topic that deserves to be examined.

Nonetheless, this does not mean that the subtitles and dubbings are "poor" translations. It is notable that the translations I have analysed do not severely alter the meaning of the Japanese script. This is a fundamental success, as translations often unintentionally alter the meaning of the original text. Scholars 
of gender and audiovisual translation have long observed this problem in translation: The gender aspects of the characters are often manipulated to serve the interests of the country or culture where the product is disseminated. Bianchi's (2008) study of the dubbing of Buffy the Vampire Slayer in Italy, Feral's (2011a) examination of the subtitles and dubbing of Sex and the City in France, as well as Chagnon's (2016) study of the dubbing of Queer as Folk and The L Word in Québec all show how an audiovisual product can be manipulated to serve the hegemonic ideals of masculinity or femininity of a specific place and time. Hence, in the case of Perfect Blue, even if the subtitles and dubbings do not completely reflect or take into account the specific 1PPs, 2PPs and SFPs of the Japanese script's yakuwarigo, the fact that the translations are a close rendition of the script means that Kon's feminist message remains undiluted and unchanged.

Kon encoded a feminist message into Perfect Blue, one that criticises how Japanese society treats women as objects for consumption, particularly idols. The scriptwriters, Kon Satoshi and Murai Sadayuki, decided to give Mima and the other characters in Perfect Blue a specific yakuwarigo that would communicate to Japanese viewers the characters' positions in Japanese society and in respect to each other. Mima's yakuwarigo is one that does not follow the stereotypical language of a female character in anime, as shown in this work. Kon and Murai wanted to push a specific feminist message not only in the film's images and script, but also in the language employed by its main character, Kirigoe Mima.

Hiramoto (2013: 75) argues that anime is a pop cultural phenomenon that usually "follows hegemonic norms", and Scott (2010) claims that the work of Kon Satoshi actually reproduces the stereotypes seen in anime. Yet this research has shown that Kon actually created strong female characters that do not follow the hegemonic norms seen in anime. Kon's message is an acid, grating criticism of Japan's strong patriarchal norms and social pressures. Kon goes against the masculine hegemony rampant in anime and Japanese society, and even though Perfect Blue was released in 1997, the issues that Kon criticises in his film still persist in Japan today. Kon's gender portrayals—and the encoded criticismsare maintained in the translation and reinforced through the film's images. As a result, Kon's critique of Japanese society and idol culture remains intact in the translation, and I can only hope that both Japanese and English-speaking audiences revisit this film, and "reflect" on the issues Kon wanted to address. 


\section{References}

Allison, Anne. (2006) Millennial Monsters: Japanese Toys and the Global Imagination. Oakland: University of California Press.

AsimaKoulas, Dimitris. (2012) "Dude (Looks Like a Lady): Hijacking Transsexual Identity in the Subtitled Version of Strella by Panos Koutras." The Translator 18:1, pp. 47-75.

BIANCHI, Diana. (2008) "Taming Teen-Language: The Adaptation of Buffyspeak into Italian." In: Chiaro, Delia; Christine Heiss \& Chiara Bucaria (eds.) 2008. Between Text and Image: Updating Research in Screen Translation. Amsterdam: John Benjamins, pp. 183-195.

Chamberlain, Lori. (1988) "Gender and the Metaphorics of Translation." In: Venuti, Lawrence (ed.) 1992. Rethinking Translation: Discourse, Subjectivity, Ideology. London \& New York: Routledge, pp. 57-74.

Chaume, Frederic. (2004) Cine y traducción. Madrid: Cátedra.

ChiAro, Delia. (2007) "Not in front of the children? An analysis of sex on screen in Italy." In: Remael, Aline \& Josélia Neves (eds.)2007. Linguistica Antverpiensia Themes in Translation Studies 6, pp. 255-276. Electronic version: <https://lans. ua.ac.be/index.php/LANS-TTS/article/view/191/122>

CONDry, Ian. (2013) The Soul of Anime: Collaborative Creativity and Japan's Media Success Story. Durham: Duke University Press.

De MArCo, Marcella. (2006a) "Audiovisual Translation from a Gender Perspective." The Journal of Specialised Translation 6, pp. 167-184.

De MARCO, Marcella. (2006b) "Multiple Portrayals of Gender in Cinematographic and Audiovisual translation discourse." In: Carroll, Mary; Heidrun Gerzymisch-Arbogast \& Sandra Nauert (eds.) 2006. MuTra 2006: Audiovisual Translation Scenarios - Conference Proceedings. Copenhagen: MuTra. Electronic version: <http://www.translationconcepts.org/pdf/MuTra_2006_Proceedings. pdf\#page $=23>$

De MARCO, Marcella. (2012) Audiovisual Translation through a Gender Lens. Amsterdam: Rodopi.

DíAZ-CintAS, Jorge \& Pablo MuÑoz-SÁnCHEZ. (2006) "Fansubs: Audiovisual Translation in an Amateur Environment." The Journal of Specialised Translation 6, pp. 37-52.

FERAL, Anne-Lise. (2011) "Sexuality and Femininity in Translated Chick Texts." In: Von Flotow, Luise (ed.) 2011. Translating Women. Ottawa: University of Ottawa Press, pp. 183-201.

FERAL, Anne-Lise. (2011a) "Gender in Audiovisual Translation: Naturalizing Feminine Voices in the French Sex and the City." European Journal of Women's Studies 18:4, pp. 391-407. 
FURUKAWA, Hiroko. (2017) "De-Feminizing Translation: To Make Women Visible in Japanese Translation." In: Von Flotow, Luise \& Farzaneh Farahzad (eds.) 2017. Translating Women: Different Voices and New Horizons. London \& New York: Routledge, pp. 76-89

Goto-Jones, Christopher. (2009) Modern Japan: A Very Short Introduction. Oxford: Oxford University Press.

Hiramoto, Mie. (2013) "Hey, you're a girl?: Gendered expressions in the popular anime, Cowboy Bebop." Multilingua 32:1, pp. 51-78.

INOUE, Miyako. (2003) "Speech Without a Speaking Body: 'Japanese women's language' in translation." Language E Communication 23:3-4, pp. 315-330.

Josephy-Hernández, Daniel E. (2015) "No Panties! Censoring Male and Female Characters in Three Popular Anime Shows Aired in Latin America and the US." In: Various authors. 2015. $2^{\text {nd }}$ International Translation Conference: Women in Translation, Kielce: Jan Kochanowski University. Conference. Electronic version: <https://www.academia.edu/18645793/_2015_No_Panties_Censoring_Three_ Popular_Anime_Shows_in_Latin_America_and_the_USA_in_the_1990s>

Josephy-HernÁndeZ, Daniel E. (2017) "Fansubbing Hentai Anime: Users, Distribution, Censorship and Ethics." In: Orrego-Carmona, David \& Yvonne Lee (eds.) 2017. Non-Professional Subtitling. Cambridge: Cambridge Scholars Publishing, pp. 171-197.

KINSUI, Satoshi \& Hiroko YAMAKIDO. (2015) "Role Language and Character Language." Acta Linguistica Asiatica 5:2, pp. 29-41.

KotAni, Mari. (2006) "Metamorphosis of the Japanese Girl: The Girl, the HyperGirl, and the Battling Beauty." Mechademia 1, pp. 162-169.

LAKOFF, Robin Tomach. (2004) Language and Woman's Place: Text and Commentaries. Revised and Expanded Edition. Bucholtz, Mary (ed.) 2004. Oxford: Oxford University Press.

LEWIS, Elizabeth Sara. (2010) “This is My Girlfriend, Linda'. Translating Queer Relationships in Film: A Case Study of the Subtitles for Gia and a Proposal for Developing the Field of Queer Translation Studies.” In: Epstein, B. J. (ed.) 2010. In Other Words, British Centre for Literary Translation, Vol. 36, pp. 3-22.

LEWIS, Elizabeth Sara. (2006) “'Excuse Me, Who Are You?': Performance, the Gaze, and the Female in the Works of Kon Satoshi." In: Brown, Steven T. (ed.) 2006. Cinema Anime: Critical Engagements with Japanese Animation. England: Palgrave McMillian, pp. 23-43.

O'HAGAN, Minako. (2003) "Can language technology respond to the subtitler's dilemma? A preliminary study." Proceedings of the Twenty-Fifth International Conference on Translating and the Computer, 20-21 November. London: Aslib. Electronic version: <http://www.mt-archive.info/Aslib-2003-OHagan.pdf> O'HAGAN, Minako. (2009) "Putting Pleasure First: Localizing Japanese Videogames." TTR: Traduction, Terminologie, Rédaction 22:1, pp. 147-165. 
Osmond, Andrew. (2006) Satoshi Kon: The Illusionist. California: Stone Bridge Press.

Oкамото, Shigeko. (1995) “'Tasteless' Japanese: Less 'Feminine' Speech Among Young Japanese Women." In: Hall, Kira \& Mary Bucholtz (eds.) 1995. Gender Articulated: Language and the Socially Constructed Self. London: Routledge, pp. 297-328.

PARINI, Ilaria. (2012) "Censorship of Anime in Italian Distribution." Meta 57:2, pp. 325-337.

PAgliassotti, Dru; Kazumi Nagaike \& Mark MCHARry. (2013) "Editorial: Boys' Love Manga Special Section." Journal of Graphic Novels and Comics 4, pp. 1-8. PéreZ-GonZÁlez, Luis. (2014) Audiovisual Translation: Theories, Methods and Issues. London \& New York: Routledge.

RANZATO, Irene. (2012) "Gayspeak and Gay Subjects in AVT." Meta 57:2, pp. 369-384.

SAITO, Kumiko. (2014) "Magic, Shōjo, and Metamorphosis: Magical Girl Anime and the Challenges of Changing Gender Identities in Japanese Society." The Journal of Asian Studies 73:1, pp. 143-164.

SAITō, Minako. (2001) Anime. Tokusatsu. Denki no Hiroinzu. Tokyo: Chikuma Shobo Publishers. Cited using the English translation by Ishiguro Tomomi: A Heroine for the World: Heroine's Image in Tokusatsu and Denki Anime. Unpublished translation.

ScotT, Gabrielle. (2010) Violence, sexualité et double: Les représentations féminines dans Perfect Blue et Paprika de Kon Satoshi. Ph.D. thesis. Electronic version: $<$ https://papyrus.bib.umontreal.ca/xmlui/bitstream/handle/1866/4404/Scott_

Gabrielle_2010_memoire.pdf >

Shamoon, Deborah. (2012) Passionate Friendship: The Aesthetics of Girl's Culture in Japan. Hawaii: University of Hawaii Press.

SHAPIRO, Judith. (1994) "Anthropology and the Study of Gender." Surroundings: An Interdisciplinary Journal 64, pp. 446-65.

Simon, Sherry. (1996) Gender in Translation: Cultural Identity and the Politics of Transmission. London \& New York: Routledge.

TAKeuCHI, Yoshikazu. (1991) Pāfekuto Burū: Kanzen Hentai. Tokyo: Metamor Publishing.

TANAKA, Lidia. (2004) Gender, Language and Culture: A Study of Japanese Television Discourse. Amsterdam: John Benjamins.

TeSHigaWARA, Mihoko \& Satoshi Kinsui. (2011) "Modern Japanese 'Role Language' (Yakuwarigo) Fictionalised Orality in Japanese Literature and Popular Culture." Sociolinguistic Studies 5:1, pp. 37-58.

VON Flotow, Luise. (1997) Translation and Gender: Translation in the Era of Feminism. Manchester: St. Jerome Publishing \& University of Ottawa Press. 
VON Flotow, Luise. (2011) Translating Women. Ottawa: University of Ottawa Press.

Von Flotow, Luise \& Joan W. Scott. (2016) "Gender Studies and Translation Studies. 'Entre braguette' - Connecting the Transdisciplines." In: Gambier, Yves \& Luc van Doorslaer (eds.) 2016. Border Crossings: Translation Studies and other disciplines. Amsterdam: John Benjamins. pp. 349-374.

Von Flotow, Luise \& Daniel E. Josephy Hernández. (2018) "Gender Perspectives in Audiovisual Translation Studies: Ample Room for Development.” In: PérezGonzález, Luis (ed.) 2018. The Handbook of Audiovisual Translation Studies. London: Routledge, pp. 296-311.

\section{Filmography}

愛の若草物語, Ai no Wakakusa Monogatari (Little Women) (Fumio Kurokawa 1987)

美少女戦士セーラームーン, Bishōjo Senshi Sērā Mūn (Pretty Soldier Sailor Moon) (Junichi Satō 1992)

Buffy the Vampire Slayer (20th Century Fox Television 1997-2003)

ドリフターズ, Dorifutazu (Drifters) (Kenichi Suzuki 2016)

風夏, Fuuka (Keizō Kusakawa 2017)

響け! ユーフォニアム, Hibike! Yūfoniamu (Sound! Euphonium) (Tatsuya Ishihara 2015)

カードキャプターさくら, Kādokyaputā Sakura (Cardcaptor Sakura) (Morio Asaka 1998)

妄想代理人, Mōsō Dairinin (Paranoia Agent) (Satoshi Kon, 2005)

パーフェクトブルー, Pāfekuto Burū (Perfect Blue) (Satoshi Kon, 1997)

パプリカ Papurika (Paprika) (Satoshi Kon, 2006)

Queer as Folk (Showcase Television 2000-2005)

千年女優, Sennen Joyū (Millennium Actress) (Satoshi Kon, 2001)

Sex and the City (HBO 1998-2004)

The L Word (Showtime Networks 2004-2009)

東京ゴッドファーザーズ, Tōkyō Goddofāzāzu (Tokyo Godfathers) (Satoshi Kon, 2003) 


\section{BIONOTE / NOTA BIOGRÁFICA}

Daniel E. Josephy-HeRnÁndez holds a PhD in Translation Studies from the University of Ottawa. His gender-focused dissertation explores the subtitles and the dubbing of the Kon Satoshi (1964-2010) film Perfect Blue (1997). He spent a research period (2014-2015) at Tōhoku Gakuin University in Sendai, Japan. His research concentrates mostly on gender and audiovisual translation in anime, focusing on critical analyses of hegemonic gender portrayals in the medium. He also studies the censorship and distribution of anime, including that of hentai (pornographic) anime, as well as the translation of anime dialects. In addition, he has published work on video game translation, graphic novels, translation in Wales and film censorship in Iran. He is passionate about gender issues in Japan, and speaks Japanese fluently, amongst several languages.

Daniel E. Josephy-Hernández es doctor en Estudios de Traducción en la Universidad de Ottawa. Su tesis analiza los subtítulos y el doblaje (desde una perspectiva de género) de la película Perfect Blue (1997), dirigida por Kon Satoshi (1964-2010). En el año 2014-2015 realizó un período de investigación en la Universidad Tōhoku Gakuin en Sendai (Japón). Sus investigaciones se concentran en el género y la traducción audiovisual y, sobre todo, en el análisis crítico de las representaciones hegemónicas de género en el anime. Además, estudia la censura y distribución del anime y el anime hentai (pornográfico) y la traducción de los dialectos en el anime. También ha publicado acerca de la traducción de videojuegos, las novelas gráficas, la traducción en Gales y la censura de películas en Irán. Le apasiona el tema de relaciones de género en Japón y habla japonés de manera fluida, entre otros idiomas. 